\title{
Urinary Tract Infections of Escherichia coli Strains of Chaperone-Usher System
}

\author{
BEATA M. ZALEWSKA-PIĄTEK* \\ Department of Microbiology, Gdańsk University of Technology, Gdańsk, Poland \\ Received 12 October 2011, revised 28 October 2011, accepted 30 October 2011
}

\begin{abstract}
Urinary tract infections are a very serious health and economic problem affecting millions of people each year worldwide. The most common etiologic agent of this type of bacterial infections, involving the upper and lower urinary tract, are E. coli strains representing approximately $80 \%$ of cases. Uropathogenic E. coli strains produce several urovirulence factors which can be divided into two main types, surface virulence factors and exported virulence factors. Surface-exposed structures include mainly extracellular adhesive organelles such as fimbriae/pili necessary in adhesion, invasion, biofilm formation and cytokine induction. Among the surface-exposed polymeric adhesive structures there are three most invasive groups, type 1 pili, type $\mathrm{P}$ pili and Dr family of adhesins which are bioassembled via the conserved, among Gram-negative bacteria, chaperone-usher secretion system. Type 1 and P-piliated E. coli cause cystitis and pyelonephritis. The Dr family of adhesins recognizing DAF receptor is responsible for cystitis, pyelonephritis (especially in pregnant women) and diarrhoea (in infants). In addition, Dr-positive E. coli strains carry the risk of recurrent urinary tract infections. Pyelonephritis in pregnant women leads to a series of complications such as bacteremia, urosepsis, acute respiratory distress syndrome and even death. In the era of increasing drug resistance of bacteria, the development of vaccines, drugs termed pilicides and inhibitors of adhesion may be a promising tool in the fight against urogenital infections.
\end{abstract}

Key words: chaperone-usher, uropathogenic E. coli, cystitis, pyelonephritis

\section{Urinary tract infections caused by Escherichia coli}

Urinary tract infections (UTIs) involving the bladder (cystitis) or the kidneys (pyelonephritis) are the most common bacterial infections. Escherichia coli strains are the major infecting agent (identified in $75-80 \%$ of analyzed cases) colonizing the urinary tract. UTIs affect more than $60 \%$ of women during their lifetime, about $25 \%$ of them have a second episode of urologic disease within 6 months because of recurrence (Milar and Cox, 1997; Hooton and Levy, 2001; Foxman, 2002; 2003a; Ronald, 2002; Foxman and Brown, 2003b).

UTIs can have severe, recurrent or chronic course. The classification of UTIs in most cases depends on the part of urinary tract which is actually colonized by the pathogenic bacteria. Lower UTIs including cystitis are the primary sites of infections in about $95 \%$. Cystitis is connected with pelvic discomfort, frequent voiding and suprapubic pain. Acute pyelonephritis, a complication that involves the kidneys (upper UTIs) is identified by the characteristic clinical symptoms, such as fever, nausea, flank pain and, sometimes vomitting. In pregnant women E. coli strains as a primary cause of pyelonephritis account for $65-80 \%$ of cases (Milar and Cox, 1997). Pyelonephritis in these kinds of patients can lead to serious consequences like urosepsis, bacteremia, acute respiratory syndrome and even death (Ventura et al., 1997). The stages of pregnancy development can be also disordered and result in intrauterine growth retardation and preterm labor (Cunningham and Lucas, 1994).

Urinary disease can be characterized by stormy clinical symptoms or especially in recurrent infection the illness can take its asymptomatic course. Elder children complain of acute stomachache, pollakiuria, painfull vesical tenesmus, nausea, vomiting, constipation or diarrhea and fever. In newborn babies and infants the clinical symptoms of UTIs are non-specific and localized outside the urinary tract. The symptoms include fever or hypothermia, aversion towards sucking, flatulence of stomach, prolonged jaundice, anxiety, cyanosis or pallor skin. The illness can also has a form of septicemia (Watson, 1994; Wyszyńska, 1994; Lewczyk and Jankowski, 2003). In adults the symptoms are very similar to elder children and include pollakiuria, fever, nausea, headache, stomachache, difficulty

\footnotetext{
* Corresponding author: B. Zalewska-Piątek, Department of Microbiology, Gdańsk University of Technology; G. Narutowicza 11/12, 80-952 Gdańsk, Poland; phone/fax (+48) 58 3471822; e-mail: beazalew@pg.gda.pl
} 
or pain on urination (dysuria), low back and pubic pain (Sobotová, 2011).

The development of urinary tract infection and its course depends on general defensive mechanisms of organism, the property of pathogenic factors, diagnosis and applied treatment (Wyszyńska, 1994; Sobotová, 2011).

\section{Virulence factors of uropathogenic Escherichia coli}

Uropathogenic strains of E. coli (UPEC) harbour different virulence factors which enable them colonization and persistence in the urinary tract. The virulence factors are encoded by genes located at the selected regions of chromosomal DNA, plasmids and transpozons. The DNA fragments forming a complex of virulence determinants (adhesins, toxins, secretion mechanisms, capsules and iron uptake systems) are called pathogenicity islands (PAIs). PAIs are flexible genetic elements, holding the mobility sequences, which are transferred horizontally between the bacterial cells (the mechanism of gene transfer important in the evolution of UPEC virulence) (Blum et al., 1994; Picard et al., 1999; Hacker and Kaper, 2000; Johnson and Kuskowski, 2000; Oelschlaeger et al., 2002; Johnson, 2003).

Virulence determinants associated with UPEC include the family of adhesive fimbrial organelles, fimbrial polyadhesins and adhesive pili ( $\mathrm{P}$ and type 1 pili, Dr family of adhesins, S and F1C fimbriae), polysacharide coatings (group II capsules), toxins (hemolysin, secreted autotransporter toxin, Sat and cytotoxic necrotizing factor), and siderophores (aerobactin system) (Oelschlaeger et al., 2002; Emödy et al., 2003; Arisoy et al., 2006; Yamamoto, 2007).

Pili and fimbriae are necessary for attachment to specific uroepithelial cells which can activate mechanisms facilitating bacterial multiplications, invasion and sometimes growth as a biofilm. The presence of pili (especially type 1 pili) can also promote the development of local inflammation (Mulvey et al., 1998). Among binding targets, host cell receptors, of adhesive fimbrial structures are manno-oligosaccharides (Connell et al., 1996; Thankavel et al., 1997; BahraniMougeot et al., 2002), digalactoside component of glycosphingolipids (Roberts et al., 1994), glycoproteins and proteins (CD55/decay accelerating factor, DAF and carcinoembryonic antigen-related molecules, CEACAMs) (Nowicki et al., 1988; 2001; Berger et al., 2004; Servin 2005; LeBougenec and Servin, 2006; Korotkova et al., 2008a; 2008b; Guignot et al., 2009).

Among the most frequent urovirulence factors with filamentous morphology are type 1 pili, $\mathrm{P}$ pili and $\mathrm{Dr}$ family of adhesins. Type 1 pili causes cystitis associated with the ability of bacteria to recognize the monomannosyl residues, localized on the bladder epithelium (Sokurenko et al., 1997). However, P pili by recognition of $\mathrm{P}$ antigen in the renal tubular epithelium leads to acute pyelonephritis (Källenius et al., 1981). In pregnant patients with pyelonephritis, P- and Dr-positve E. coli strains (representing gestational age-dependent profiles) predominate during the second and third trimester, respectively (Nowicki et al., 1994).

The Dr adhesins are the third most common group of colonization factors of UPEC, behind type 1 and $P$ pili (Nowicki et al., 2001). They are responsible for $25-50 \%$ cases of cystitis and $30 \%$ of pyelonephritis in pregnant woman (Labigne-Roussel and Falkow, 1988). Dr adhesins can also increase the risk of recurrent UTIs (Foxman et al., 1995).

The growing Dr superfamily of adhesins includes Dr hemagglutinin (Dr/DraE adhesin), Dr-II, F1845, Afa-I, -II, -III, -IV, -V, -VII and -VIII, Nfa-I, Aaf-I and Aaf-II (of human or animal origin). All the adhesins are encoded by gene clusters of similar organization. In most cases, they bind to the common epithelial cell receptor, DAF (Nowicki et al., 2001; Servin 2005; Le Bougenec and Servin, 2006). Interaction of the Dr adhesin with DAF glycoprotein leads to the internalization of bacterial cells to the epithelial cells. $\mathrm{Dr}^{+}$E. coli strains are able to survive long-term in human epithelial cells (Goluszko et al., 1997; 1999). In the kidneys of experimental animals the above E. coli strains can also persist for several months (Selvarangan et al., 2004).

Dr hemagglutinin among the whole family of Dr adhesin is the only member which can bind to type IV collagen (Westerlund et al., 1989; Carnoy and Moseley, 1997). DrI113T mutant totally lost its ability to bind type IV collagen (Carnoy and Moseley, 1997; Selvarangan et al., 2004). Besides type IV collagen and DAF, the DraE adhesin can interact with members of the carcinoembryonic antigen family, CEA-related cellular adhesion molecules, CEACAM1, CEACAM5 and CEACAM6 (Berger et al., 2004; Korotkova et al., 2008a; 2008b; Guignot et al., 2009). Dr haemagglutinin also triggers the bacterial mobilization of $\alpha_{5} \beta_{1}$ integrin (Guignot et al., 2009).

The capsule material on the bacterial surface provides protection against complement mediated bactericidal effect in the host organism and phagocytic engulfment. LPS molecules induce the cytokine synthesis (IL-1, TNFa) and stimulate the inflammantory response (Morrison and Ryan, 1987; Rietschel, et al., 1996). Other surface located molecules can form a part of a secretory machinery of virulence factors exported outside the bacterial cells like the outer membrane haemin receptor protein termed ChuA (required to gain access to the source of iron ions) (Torres and Payne, 1997). 
Exported virulence factor, $\alpha$-hemolysin, is responsible for a destruction of cytoplasmic membrane of erythrocytes, endothelial and renal epithelial cells which causes uncontrolled outflow of ions from the cells (Smith, 1963; Keane et al., 1987). The serine autotransporter protease, Sat, also belonging to exported determinants, reveals a toxic activity against bladder or kidney cell lines (Guyer et al., 2002). The toxin has an ability to induce vacuolization within the cytoplasm of human cells of urinary tract origin contributing to the pathogenicity of UPEC by damage of host tissues and increase of bacterial propagation. Another secreted factor, the cytotoxic necrotising factor 1, CNF1 evokes apoptosis of bladder epithelial cells (Caprioli et al., 1987; Fiorentini et al., 1997). Siderophores, like aerobactin, found in $30-60 \%$ of uropathogenic E. coli strains are low molecular weight compounds exported from the bacterial cell to gain $\mathrm{Fe}^{3+}$ cations from the host components chelating the iron. The process of iron utilization is controlled by farric-siderophore receptors located in the bacterial outer membrane (Guerinot, 1994; Braun et al., 1998; Schubert et al., 2002).

\section{Chaperone-usher pathway as the secretion mechanism of adhesive organelles of UPEC}

A multitude of Gram-negative pathogens utilize the highly conserved secretion pathway termed chaperoneusher for the bioassembly of at least 30 diverse adhesive organelles that are required in host-pathogen interactions critical for the initial step of infection (Hung et al., 1996; Thanassi et al., 1998; Sauer et al., 2004). Among those fibers, $\mathrm{P}$ and type 1 pili, expressed by uropathogenic E. coli strains, are mainly used as the model systems to understand their structure and function. The chaperone-usher secretion system is also studied on a basis of E. coli Dr family of adhesins and polymeric F1 capsular antigen of Yersinia pestis (Zavialov et al., 2003; Anderson et al., 2004; Pettigrew et al., 2004; Sauer et al., 2004; Piątek et al., 2005a; 2005b).

The chaperone-usher secretion system is based on two components, chaperone located in periplasmic space and usher inserted in the outer-membrane. Including the sequence analysis two immunoglobulin-like periplasmic chaperone families have been identified, FGL (F1-G1 long) named Caf1M-like with a long and flexible loop (21-29 residues) between F1 and G1 $\beta$-strands and FGS (F1-G1 short) named PapD-like with a short loop (10-20 residues) connecting F1 and G1 $\beta$-strands (Zav'yalov et al., 1995; Hung et al., 1996; 1998; Saulino et al. 2000; Sauer et al., 2000; Zavialov et al., 2007).

The division of chaperones is strictly connected with morphological properties of adhesive structures.
The FGL chaperone-assembled organelles, called fimbrial polyadhesins (diameter of $2 \mathrm{~nm}$ ), consist of linear polymers of one or two types of protein subunits (each subunit possesses adhesive properties). The adhesive organelles have nonpilus, amorphous or capsule likemorphology. The FGS assembled organelles, termed adhesive pili (pilus rod of $10 \mathrm{~nm}$ diameter), are composite structures built from multiple different pilus subunits with single adhesive subunit at the tip (Hung et al., 1996; Nishiyama et al., 2005; Remaut et al., 2006; Zavialov et al., 2003; 2005; 2007).

The outer membrane molecular ushers form a conserved family of proteins (Fimbrial Usher Proteins, FUP) without any specific differences in sequences involved in the assembly of fimbrial polyadhesins or adhesive pili (Thanassi et al., 2002; Capitani et al., 2006a; 2006b; Zavialov et al., 2007).

The chaperones of both families play many functions in biogenesis of pili/fimbriae. They stabilize subunits in the periplasm (after secretion via the Sec pathway) by formation of soluble chaperone-subunit complexes, cap their interactive surfaces which prevents premature interactions of the subunits, aggregation and degradation by periplasmic proteases. They also facilitate the folding of subunits after their emergence from the inner membrane in semi-unfolded conformations and transport the subunits to an outer membrane molecular usher. All functions are determined by a donor strand complementation mechanism in which G1 $\beta$-strand of the chaperone and the portion of the F1-G1 loop complete the immunoglobulin fold of the subunit (Zav'yalov et al., 1995; Hung et al., 1996; Thanassi et al., 1998; Knight et al., 2000; Sauer et al., 1999; 2000; 2004; Zavialov et al., 2001; 2003; 2005; 2007; Remaut et al., 2006).

The ushers release the subunit from the complex with the chaperone in the periplasm, form an assembly polymerization platform of subunits in linear fibers/ pilus structures and secrete adhesive organelles via the oligomeric usher pores to the bacterial cell (Nishiyama et al., 2005; Remaut et al., 2006). The pilus/fiber assembly is carried out by a donor strand exchange mechanism in which the amino terminal strand of a neighboring subunit replaces the G1 $\beta$-strand of the chaperone. Thus, in the mature adhesive organelle every subunit is required for the complementation of the immunoglobulin fold of its neighbor (Barnhart et al., 2000).

\section{Present and future treatment of UTIs}

Modern therapy of the urinary tract infections is based on their treatment with antibiotics. The choice of anti-bacterial treatment and the time of application is dependent on a clinical character of urinary tract 
infection and patient condition. One should take into consideration the course of drug action, the concentration of the medicine in urine, excretion in unaltered form, undesirable symptoms after its application and the cost of treatment. The drugs with a long-term effect and capacity of sequential treatment (initial parenteral administration of a drug and a continuation of treatment by the oral form of preparation) are recommended (Gutierrez, 1996).

Increasing resistance of bacteria to antibiotics and understanding of pathogenesis of UTIs create the need for designing chemotherapeutics that target new molecular targets (Stamm and Hooton, 1993; Hooton and Levy, 2001; White and McDrmott, 2001; Gupta, 2003). There are several potential strategies which can be used in future to treat UTIs. One strategy blocking the colonization of urinary tract by uropathogens includes inhibition of pili/fimbriae biogenesis. Another strategy concerns the process of blocking of intracellular bacterial communities (IBC) which are cellular structures similar to biofilm preventing the bacteria from immune response and antibiotic therapy. The next strategy is connected with abolishing of binding of bacterial adhesins to host cellular receptors. The most promising approaches are related to inhibition of pili/ fimbriae biogenesis and blocking of bacterial adhesion (Wright and Hultgren, 2006).

The adhesion of bacterial cells can be blocked by using small molecules, so called adhesin inhibitors which strictly interact with the target adhesins (Firon et al., 1987; Ohlsson et al., 2002; Ofek et al., 2003). Aromatic alpha-glycosides of mannose for a long time are considered to be excellent inhibitors of adhesion of type 1 piliated E. coli (mediated by FimH adhesin) to target tissues (Firon et al., 1987). Fruit juices, especially cranberry juice, are widely used in the treatment of UTIs. Positive effects of cranberry juice have also been observed in clinical trials (Avorn et al., 1994; Kontiokari et al., 2001; Di Martino etal., 2006). The active inhibition ingredient in cranberry juice is fructose (Zafriri et al., 1989). Fructose, as well as aryl mannosides, binds to FimH adhesin of type 1 pili $\sim 15$ times weaker than mannose (Bouckaert et al., 2005) (mannose-containing receptors of the bladder epithelium are critical for establishment of cystitis) (Connell et al., 1996; Thankavel et al., 1997; Bahrani-Mougeot et al., 2002), and tightly than the natural globoside, (Gala1$4 \mathrm{Gal}$ ) (globoside-containing receptors present on the kidney epithelium are necessary for pyelonephritis) (Lund etal., 1987; Roberts etal., 1994) to PapG-II adhesin of type P pili. Among several variants of PapG adhesins, PapG-II and PapG-III are predominant for colonization of the upper urinary tract (Strömberg et al., 1990; 1991; Striker et al., 1995). Galabiose derivatives apperar to be potent inhibitors of adhe- sion mediated by PapG adhesin of $p a p^{+}$E. coli strains (Ohlsson et al., 2002).

The surface adhesive organelles (pili/fimbriae) of uropathogenic E. coli strains as virulence factors target for the development of a new class of anti-infective agents called pilicides. The pilicides function by interfering with the chaperone and usher activity, thus preventing the biogenesis of pili/fimbriae (Pinkner et al., 2001; Svensson et al., 2001). Effective activity of pilicides has been demonstrated for type 1 and type $P$ pili. In this case, the reduction of biogenesis of the studied adhesive structures, was observed (Hendenström et al., 2005; Pinkner et al., 2006; Chorell et al., 2010). In both cases, inhibitors of adhesion and pilicides, further in vivo studies are required.

Among the traditional methods used in combating infectious diseases is vaccination. There are high expectations about the vaccine based on the FimCH binary complex composed of chaperone and adhesin (encoded by type 1 piliated E.coli), which was tested in mice and cynomolgus monkeys. Vaccination of the studied animals with FimCH resulted in greater than 99\% reduction of mucosal colonization (Langermann and Ballou WR Jr, 2001) and 75\% reduction in both colonization and inflammation, respectively (Langerman et al., 2000). Until now, there are no clinical trials performed on the basis of PapDG chaperone-adhesin complex (of P-piliated E. coli).

Finally, the best treatment should apply to the combination of bacterial adhesins and be directed to different sites of colonization by bacterial strains. The development of vaccines and anti-adhesive drugs can prevent anticipated and recurrent UTIs.

\section{Summary}

Urinary tract infections are very common health problem world wide. Most of these infections are caused by the uropathogenic E. coli strains (about $80 \%$ ). Virulence of the bacterial strains is mainly determined by the surface-exposed adhesive polymeric structures (fimbriae/pili) responsible for recognition of the selected cellular receptors on the target cells. Interaction of the adhesive subunits with the specific receptors on the surface of host cells is the crucial step in the pathogenesis. Strong immunogenic properties of the adhesive polymeric structures are often used to design vaccines based on the conserved antigenic domains of the adhesins (so called adhesin-based vaccines) which can be useful for the prevention of a number of different diseases. An alternative to adhesin-based vaccines is an inhibition of adhesion by using adhesin inhibitors interacting with target adhesin in many cases more tightly than the physiological ligands. Because of the 
crucial role of the adhesive organelles in the colonization of the invaded environment, their biogenesis is highly conserved among the multitude of Gram-negative bacteria. Detailed characteristics of the chaperones, a component of the chaperone-usher pathway, showed their usefulness as an ideal target for the developing of the potential drugs, termed pilicides. Such drugs, by interactions with chaperone and usher proteins, have the potential to block pili formation in a broad range of pathogenic bacteria parallel with the inhibition of adhesion and invasion of bacterial cells into the eucariotic cells.

\section{Literature}

Anderson K.L., J. Billington, D. Pettigrew, E. Cota, P. Simpson, P. Roversi, H.A. Chen, P. Urvil, L. du Merle, P.N. Barlow and others. 2004. An atomic resolution model for assembly, architecture, and function of the Dr adhesins. Mol. Cell 15: 647-657.

Arisoy M., D. Aysev, M. Ekim, D. Ozel, S.K. Köse, E.D. Ozsoy and N. Akar. 2006. Detection of virulence factors of Escherichia coli from children by multiplex polymerase chain reaction. Int. J. Clin. Pract. 60: 170-173.

Avorn J., M. Monane, J.H. Gurwitz, R.J. Glynn, I. Choodnovskiy and L.A. Lipsitz. 1994. Reduction of bacteriuria and pyuria after ingestion of cranberry juice. JAMA. 271: 751-754.

Bahrani-Mougeot F.K., E.L. Buckles, C.V. Lockatell, J.R. Hebel, D.E. Johnson, C.M. Tang and M.S. Donnenberg. 2002. Type $1 \mathrm{fim}-$ briae and extracellular polysaccharides are preeminent uropathogenic Escherichia coli virulence determinants in the murine urinary tract. Mol. Microbiol. 45: 1079-1093.

Barnhart M.M., J.S. Pinkner, G.E. Soto, F.G. Sauer, S. Langermann, G. Waksman, C. Frieden and S.J. Hultgren. PapD-like chaperones provide the missing information for folding of pilin proteins. Proc. Natl. Acad. Sci. USA. 97: 7709-7714.

Berger C.N., O. Billker, T.F. Meyer, A.L. Servin and I. Kansau. 2004. Differential recognition of members of the carcinoembryonic antigen family by Afa/Dr adhesins of diffusely adhering Escherichia coli (Afa/Dr DAEC). Mol. Microbiol. 52: 963-983.

Blum G., M. Ott, A. Lischewski, A. Ritter, H. Imrich, H. Tschäpe and J. Hacker. 1994. Excision of large DNA regions termed pathogenicity islands from tRNA-specific loci in the chromosome of an Escherichia coli wild-type pathogen. Infect. Immun. 62: 606-614.

Bouckaert J., J. Berglund, M. Schembri, E. De Genst, L. Cools, M. Wuhrer, C.S. Hung, J. Pinkner, R. Slättegård, A. Zavialov and others. 2005. Receptor binding studies disclose a novel class of high-affinity inhibitors of the Escherichia coli FimH adhesin. Mol. Microbiol. 55: 441-455.

Braun V., K. Hantke and W. Köster. 1998. Bacterial iron transport: mechanisms, genetics, and regulation. Met. Ions Biol. Syst. 35: 67-145.

Capitani G., O. Eidam, R. Glockshuber and M.G. Grütter. 2006a. Structural and functional insights into the assembly of type 1 pili from Escherichia coli. Microbes Infect. 8: 2284-2290.

Capitani G., O. Eidam and M.G. Grütter. 2006b. Evidence for a novel domain of bacterial outer membrane ushers. Proteins 65: 816-823.

Caprioli A., V. Falbo, F.M. Ruggeri, L. Baldassarri, R. Bisicchia, G. Ippolito, E. Romoli and G. Donelli. 1987. Cytotoxic necrotizing factor production by hemolytic strains of Escherichia coli causing extraintestinal infections. J. Clin. Microbiol. 25: 146-149.
Carnoy C. and S.L. Moseley. 1997. Mutational analysis of receptor binding mediated by the Dr family of Escherichia coli adhesins. Mol. Microbiol. 23: 365-379.

Chorell E., J.S. Pinkner, G. Phan, S. Edvinsson, F. Buelens, H. Remaut, G. Waksman, S.J. Hultgren and F. Almqvist. 2010. Design and synthesis of C-2 substituted thiazolo and dihydrothiazolo ring-fused 2-pyridones: pilicides with increased antivirulence activity. J. Med. Chem. 53: 5690-5695.

Connell I., W. Agace, P. Klemm, M. Schembri, S. Mărild and C. Svanborg. 1996. Type 1 fimbrial expression enhances Escherichia coli virulence for the urinary tract. Proc. Natl. Acad. Sci. USA. 93: 9827-9832.

Cunningham F.G. and M.J. Lucas. 1994. Urinary tract infections complicating pregnancy. Baillieres Clin. Obstet. Gynaecol. 8: 353-373. Di Martino P., R. Agniel, K. David, C. Templer, J.L. Gaillard, P. Denys and H. Botto. 2006. Reduction of Escherichia coli adherence to uroepithelial bladder cells after consumption of cranberry juice: a double-blind randomized placebo-controlled cross-over trial. World J. Urol. 4: 21-27.

Emödy L., M. Kerényi and G. Nagy. 2003. Virulence factors of uropathogenic Escherichia coli. Int. J. Antimicrob. Agents. 2: 29-33. Fiorentini C., A. Fabbri, P. Matarrese, L. Falzano, P. Boquet and W. Malorni. 1997. Hinderance of apoptosis and phagocytic behaviour induced by Escherichia coli cytotoxic necrotizing factor 1: two related activities in epithelial cells. Biochem. Biophys. Res. Commun. 241: 341-346.

Firon N., S. Ashkenazi, D. Mirelman, I. Ofek and N. Sharon. 1987. Aromatic alpha-glycosides of mannose are powerful inhibitors of the adherence of type 1 fimbriated Escherichia coli to yeast and intestinal epithelial cells. Infect. Immun. 55: 472-476.

Foxman B., L. Zhang, P. Tallman, K. Palin, C. Rode, C. Bloch, B. Gillespie and C.F. Marrs. 1995. Virulence characteristics of Escherichia coli causing first urinary tract infection predict risk of second infection. J. Infect. Dis. 172: 1536-1541.

Foxman B. 2002. Epidemiology of urinary tract infections: incidence, morbidity, and economic costs. Am. J. Med. 113 Suppl. 1A: 5S-13S. Foxman B. 2003a. Epidemiology of urinary tract infections: incidence, morbidity, and economic costs. Dis. Mon. 49: 53-70.

Foxman B. and P. Brown. 2003b. Epidemiology of urinary tract infections: transmission and risk factors, incidence, and costs. Infect. Dis. Clin. North. Am. 17: 227-241.

Goluszko P., S.L. Moseley, L.D. Truong, A. Kaul, J.R. Williford, R. Selvarangan, S. Nowicki and B. Nowicki. 1997. Development of experimental model of chronic pyelonephritis with Escherichia coli O75:K5:H-bearing Dr fimbriae: mutation in the dra region prevented tubulointerstitial nephritis. J. Clin. Invest. 99: 1662-1672. Goluszko P., R. Selvarangan, V. Popov, T. Pham, J.W. Wen and J. Singhal. 1999. Decay-accelerating factor and cytoskeleton redistribution pattern in HeLa cells infected with recombinant Escherichia coli strains expressing Dr family of adhesins. Infect. Immun. 67: 3989-3997.

Guerinot M.L. 1994. Microbial iron transport. Annu. Rev. Microbiol. 48: 743-772.

Guignot J., S. Hudault, I. Kansau, I. Chau and A.L. Servin. 2009. DAF and CEACAMs receptor-mediated internalization and lifestyle of Afa/Dr diffusely adhering Escherichia coli into epithelial cells. Infect. Immun. 77: 517-531.

Gupta K. 2003. Emerging antibiotic resistance in urinary tract pathogens. Infect. Dis. Clin. North. Am. 17: 243-259.

Gutierrez K. 1996. Continuation of antibiotic therapy for serious bacterial infections outside of the hospital. Pediatr. Ann. 25: 639-645. Guyer D.M., S. Radulovic, F.E. Jones and H.L. Mobley. 2002. Sat, the secreted autotransporter toxin of uropathogenic Escherichia coli, is a vacuolating cytotoxin for bladder and kidney epithelial cells. Infect. Immun. 70: 4539-4546. 
Hedenström M., H. Emtenäs, N. Pemberton, V. Aberg, S.J. Hultgren, J.S. Pinkner, V. Tegman, F. Almqvist, I. Sethson and J. Kihlberg. 2005. NMR studies of interactions between periplasmic chaperones from uropathogenic E. coli and pilicides that interfere with chaperone function and pilus assembly. Org. Biomol. Chem. 3: 4193-4200.

Hacker J. and J.B. Kaper. 2000. Pathogenicity islands and the evolution of microbes. Annu. Rev. Microbiol. 54: 641-679.

Hooton T. M. 2001. Recurrent urinary tract infection in women. Int. J. Antimicrob. Agents. 17: 259-268.

Hooton T.M. and S.B. Levy. 2001. Antimicrobial resistance: a plan of action for community practice. Am. Fam. Physician. 63: 1087-1098. Hung D.L., S.D. Knight, R.M. Woods, J.S. Pinkner and S.J. Hultgren. 1996. Molecular basis of two subfamilies of immunoglobulinlike chaperones. EMBO J. 15: 3792-3805.

Johnson J.R. and M. Kuskowski. 2000. Clonal origin, virulence factors, and virulence. Infect. Immun. 68: 424-425.

Johnson J.R. 2003. Microbial virulence determinants and the pathogenesis of urinary tract infection. Infect. Dis. Clin. North. Am. 17: 261-278.

Källenius G., R. Möllby, S.B. Svenson, I. Helin, H. Hultberg, B. Cedergren and J. Winberg. 1981. Occurrence of P-fimbriated Escherichia coli in urinary tract infections. Lancet. 2: 1369-1372.

Keane W.F., R. Welch, G. Gekker and P.K. Peterson. 1987. Mechanism of Escherichia coli alpha-hemolysin-induced injury to isolated renal tubular cells. Am. J. Pathol. 126: 350-357.

Knight S.D., J. Berglund and D. Choudhury. 2000. Bacterial adhesins: structural studies reveal chaperone function and pilus biogenesis. Curr. Opin. Chem. Biol. 4: 653-660.

Kontiokari T., K. Sundqvist, M. Nuutinen, T. Pokka, M. Koskela and M. Uhari. 2001. Randomised trial of cranberry-lingonberry juice and Lactobacillus GG drink for the prevention of urinary tract infections in women. BMJ. 322:1571.

Korotkova N., Y. Yang, I. Le Trong, E. Cota, B. Demeler, J. Marchant, W.E. Thomas, R.E. Stenkamp, S.L. Moseley and S. Matthews. 2008a. Binding of Dr adhesins of Escherichia coli to carcinoembryonic antigen triggers receptor disssociation. Mol. Microbiol. 67: 420-434.

Korotkova N., Y. Yarova-Yarovaya, V. Tchesnokova, N. Yazvenko, M.A. Carl, A.E. Stapleton and S.L. Moseley. 2008b. Escherichia coli DraE adhesin-associated bacterial internalization by epithelial cells is promoted independently by decay-accelerating factor and carcinoembryonic antigen-related cell adhesion molecule binding and does not require the DraD invasin. Infect. Immun. 76: 3869-3880. Labigne-Roussel A. and S. Falkow. 1988. Distribution and degree of heterogeneity of the afimbrial-adhesin-encoding operon ( $a f a$ among uropathogenic Escherichia coli isolates. Infect. Immun. 56: 640-648. Langermann S., R. Möllby, J.E. Burlein, S.R. Palaszynski, C.G. Auguste, A. DeFusco, R. Strouse, M.A. Schenerman, S.J. Hultgren, J.S. Pinkner and others. 2000. Vaccination with FimH adhesin protects cynomolgus monkeys from colonization and infection by uropathogenic Escherichia coli. J. Infect. Dis. 181: 774-778.

Langermann S. and W.R. Jr Ballou. 2001. Vaccination utilizing the FimCH complex as a strategy to prevent Escherichia coli urinary tract infections. J. Infect. Dis. 183 Suppl 1: S84-S86.

Le Bouguénec C. and A.L. Servin. 2006. Diffusely adherent Escherichia coli strains expressing Afa/Dr adhesins (Afa/Dr DAEC): hitherto unrecognized pathogens. FEMS Microbiol. Lett. 256: 185-194. Lewczyk E. and S. Jankowski. 2003. Urinary tract infections in children (in Polish). Adv. Clin. Exp. Med. 12: 375-380.

Lund B., F. Lindberg, B.I. Marklund and S. Normark. 1987. The PapG protein is the alpha-D-galactopyranosyl- $(1 \rightarrow 4)$-beta-Dgalactopyranose-binding adhesin of uropathogenic Escherichia coli. Proc. Natl. Acad. Sci. USA. 84: 5898-5902.

Millar L.K. and S. M. Cox. 1997. Urinary tract infections complicating pregnancy. Infect. Dis. Clin. North. Am. 11: 13-26.
Morrisom D.C. and J.L. Ryan. 1987. Endotoxins and disease mechanisms. Annu. Rev. Med. 38: 417-432.

Mulvey M.A., Y.S. Lopez-Boado, C.L. Wilson, R. Roth, W.C. Parks, J. Heuser and S.J. Hultgren. 1998. Induction and evasion of host defenses by type 1-piliated uropathogenic Escherichia coli. Science. 282: 1494-1497.

Nishiyama M., R. Horst, O. Eidam, T. Herrmann, O. Ignatov, M. Vetsch, P. Bettendorff, I. Jelesarov, M.G. Grütter, K. Wüthrich and others. 2005. Structural basis of chaperone-subunit complex recognition by the type 1 pilus assembly platform FimD. EMBO J. 24: 2075-2086.

Nowicki B., J. Moulds, R. Hull and S. Hull. 1988. A hemagglutinin of uropathogenic Escherichia coli recognizes the Dr blood group antigen. Infect. Immun. 56: 1057-1060.

Nowicki B., M. Martens, A. Hart and S. Nowicki. 1994. Gestational age-dependent distribution of Escherichia coli fimbriae in pregnant patients with pyelonephritis. Ann. NY Acad. Sci. 730: 290-91.

Nowicki B., R. Selvarangan and S. Nowicki. 2001. Family of Escherichia coli Dr adhesins: decay-accelerating factor receptor recognition and invasiveness. J. Infect. Dis. Suppl 1 183: S24-27.

Oelschlaeger T.A., U. Dobrindt and J. Hacker. 2002. Pathogenicity islands of uropathogenic E. coli and the evolution of virulence. Int. J. Antimicrob. Agents. 19: 517-521.

Ofek I., D.L. Hasty and N. Sharon. 2003. Anti-adhesion therapy of bacterial diseases: prospects and problems. FEMS Immunol. Med. Microbiol. 38: 181-191.

Ohlsson J., J. Jass, B.E. Uhlin, J. Kihlberg and U.J. Nilsson. 2002. Discovery of potent inhibitors of PapG adhesins from uropathogenic Escherichia coli through synthesis and evaluation of galabiose derivatives. Chembiochem. 3: 772-779.

Piątek R., B. Zalewska, O. Kolaj, M. Ferens, B. Nowicki and J. Kur. 2005a. Molecular aspects of biogenesis of Escherichia coli Dr fimbriae: characterization of DraB-DraE complexes. Infect. Immun. 73: 135-145.

Piątek R., B. Zalewska, K. Bury and J. Kur. 2005b. The chaperoneusher pathway of bacterial adhesin biogenesis - from molecular mechanism to strategies of anti-bacterial prevention and modern vaccine design. Acta Biochim. Pol. 52: 639-46.

Picard B., J.S. Garcia, S. Gouriou, P. Duriez, N. Brahimi, E. Bingen, J. Elion and E. Denamur. 1999. The link between phylogeny and virulence in Escherichia coli extraintestinal infection. Infect. Immun. 67: 546-553.

Pinkner J.S., H. Remaut, F. Buelens, E. Miller, V. Aberg, N. Pemberton, M. Hendenström, A. Larsson, P. Seed, G. Waksaman and others. 2006. Rationally designed small compounds inhibit pilus biogenesis in uropathogenic bacteria. Proc. Natl. Acad. Sci. USA. 103: 17897-17902.

Pettigrew D., K.L. Anderson, J. Billington, E. Cota, P. Simpson, P. Urvil, F. Rabuzin, P. Roversi, B. Nowicki, L. du Merle and others. 2004. High resolution studies of the Afa/Dr adhesin DraE and its interaction with chloramphenicol. J. Biol. Chem. 279: 46851-46857. Remaut H., R.J. Rose, T.J. Hannan, S.J. Hultgren, S.E. Radford, A.E. Ashcroft and G. Waksman. 2006. Donor-strand exchange in chaperone-assisted pilus assembly proceeds through a concerted beta strand displacement mechanism. Mol. Cell. 22: 831-842.

Rietschel E.T., H. Brade, O. Holst, L. Brade, S. Müller-Loennies, U. Mamat, U. Zähringer, F. Beckmann, U. Seydel, K. Brandenburg and others. 1996. Bacterial endotoxin: chemical constitution, biological recognition, host response, and immunological detoxification. Curr. Top Microbiol. Immunol. 216: 39-81.

Roberts J.A., B.I. Marklund, D. Ilver, D. Haslam, M.B. Kaack, G. Baskin, M. Louis, R. Möllby, J. Winberg and S. Normark. 1994. The Gal(alpha 1-4)Gal-specific tip adhesin of Escherichia coli P-fimbriae is needed for pyelonephritis to occur in the normal urinary tract. Proc. Natl. Acad. Sci. USA. 91: 11889-11893. 
Ronald A. 2002. The etiology of urinary tract infection: traditional and emerging pathogens. Am. J. Med. 113 Suppl 1A: 14S-19S.

Selvarangan R., P. Goluszko, J. Singhal, C. Carnoy, S. Moseley, B. Hudson, S. Nowicki and B. Nowicki. 2004. Interaction of Dr adhesin with collagen type IV is a critical step in Escherichia coli renal persistence. Infect. Immun. 72: 4827-4835.

Saulino E.T., E. Bullitt and S.J. Hultgren. 2000. Snapshots of ushermediated protein secretion and ordered pilus assembly. Proc. Natl. Acad. Sci.USA. 97: 9240-9245.

Sauer F.G., K. Futterer, J.S. Pinkner, K.W. Dodson, S.J. Hultgren and G. Waksman. 1999. Structural basis of chaperone function and pilus biogenesis. Science 285: 1058-1061.

Sauer F.G., M. Barnhart, D. Choudhury, S.D. Knight, G. Waksman and S.J. Hultgren. 2000. Chaperone-assisted pilus assembly and bacterial attachment. Curr. Opin Struct Biol. 10: 548-556.

Sauer F.G., H. Remaut, S.J. Hultgren and G. Waksman. 2004. Fiber assembly by the chaperone-usher pathway. Biochim. Biophys. Acta. 1694: 259-267.

Schubert S., B. Picard, S. Gouriou, J. Heesemann and E. Denamur. 2002. Yersinia high-pathogenicity island contributes to virulence in Escherichia coli causing extraintestinal infections. Infect. Immun. 70: 5335-5337.

Servin A.L. 2005. Pathogenesis of Afa/Dr diffusely adhering Escherichia coli. Int. J. Med. Microbiol. 295: 471-478.

Selvarangan R., P. Goluszko, J. Singhal, C. Carnoy, S. Moseley, B. Hudson, S. Nowicki and B. Nowicki. 2004. Interaction of Dr adhesin with collagen type IV is a critical step in Escherichia coli renal persistence. Infect. Immun. 72: 4827-4835.

Smith H.W. 1963. The haemolysins of Escherichia coli. J. Pathol. Bacteriol. 85: 197-211.

Sobotová D. 2011. Urinary tract infections and chronic renal failure. Vnitr. Lek. 57: 626-630.

Sokurenko E.V., V. Chesnokova, R.J. Doyle and D.L. Hasty. 1997. Diversity of the Escherichia coli type 1 fimbrial lectin. Differential binding to mannosides and uroepithelial cells. J. Biol. Chem. 272: 17880-17886.

Stamm W.E. and T.M. Hooton. 1993. Management of urinary tract infections in adults. N. Engl. J. Med. 329: 1328-1334.

Striker R., U. Nilsson, A. Stonecipher, G. Magnusson and S.J. Hultgren. 1995. Structural requirements for the glycolipid receptor of human uropathogenic Escherichia coli. 6: 1021-1029.

Strömberg N., B.I. Marklund, B. Lund, D. Ilver, A. Hamers, W. Gaastra, K.A. Karlsson and S. Normark. 1990. Host-specificity of uropathogenic Escherichia coli depends on differences in binding specificity to Gal alpha $1-4 \mathrm{Gal}$-containing isoreceptors. EMBO J. 9: 2001-2010.

Strömberg N., P.G. Nyholm, I. Pascher and S. Normark. 1991. Saccharide orientation at the cell surface affects glycolipid receptor function. Proc. Natl. Acad. Sci. USA. 88: 9340-9344.

Svensson A., A. Larsson, H. Emtenäs, M. Hedenström, T. Fex, S.J. Hultgren, J.S. Pinkner, F. Almqvist and J. Kihlberg. 2001. Design and evaluation of pilicides: potential novel antibacterial agents directed against uropathogenic Escherichia coli. Chembiochem. 2: 915-918.

Thanassi D.G., E.T. Saulino and S.J. Hultgren. 1998. The chaperone/usher pathway: a major terminal branch of the general secretory pathway. Curr. Opin. Microbiol. 1: 223-231.
Thanassi D.G., C. Stathopoulos, K. Dodson, D. Geiger and S.J. Hultgren. 2002. Bacterial outer membrane ushers contain distinct targeting and assembly domains for pilus biogenesis. J. Bacteriol. 184: 6260-6269.

Thankavel K., B. Madison, T. Ikeda, R. Malaviya, A.H. Shah, P.M. Arumugam and S.N. Abraham. 1997. Localization of a domain in the FimH adhesin of Escherichia coli type 1 fimbriae capable of receptor recognition and use of a domain-specific antibody to confer protection against experimental urinary tract infection. Clin. Invest. 100: 1123-3116.

Torres A.G. and S.M. Payne. 1997. Haem iron-transport system in enterohaemorrhagic Escherichia coli O157:H7. Mol. Microbiol. 23: 825-833.

Ventura J.E., M. Villa, R. Mizraji and R. Ferreiros. 1997. Acute renal failure in pregnancy. Ren. Fail. 19: 217-220.

Watson A.R. 1994. Urinary tract infection in early childhood. J. Antimicrob. Chemother. 34 Suppl A: 53-60.

Westerlund B., P. Kuusela, J. Risteli, L. Risteli, T. Vartio, H. Rauvala, R. Virkola and T.K. Korhonen. 1989. The O75X adhesin of uropathogenic Escherichia coli is a type IV collagen-binding protein. Mol. Microbiol. 3: 329-337.

White D.G. and P.F. McDrmott. 2001. Biocides, drug resistance and microbial evolution. Curr. Opin. Microbiol. 4: 313-317.

Wright K.J. and S.J. Hultgren. 2006. Sticky fibers and uropathogenesis: bacterial adhesins in the urinary tract. Future Microbiol. 1: 75-87. Wyszyńska T. 1994. Urinary tract infections in children (in Polish). Klin. Pediatr. 2: 17-24.

Yamamoto S. 2007. Molecular epidemiology of uropathogenic Escherichia coli. J. Infect. Chemother. 13: 68-73.

Zafriri D., I. Ofek, R. Adar, M. Pocino and N. Sharon. 1989. Inhibitory activity of cranberry juice on adherence of type 1 and type $\mathrm{P}$ fimbriated Escherichia coli to eucaryotic cells. Antimicrob. Agents Chemother. 33: 92-98.

Zavialov A.V., N.V. Batchikova, P. Korpela, L.E. Petrovskaya, V.G. Korobko, J. Kersley, S. MacIntyre and V.P. Zav'yalov. 2001. Secretion of recombinant proteins via the chaperone/usher pathway in Escherichia coli. Appl. Environ. Microbiol. 67: 1805-1814.

Zavialov A.V., J. Kersley, T. Korpela, V.P. Zav'yalov, S. MacIntyre and S.D. Knight. 2002. Donor strand complementation mechanism in the biogenesis of non-pilus systems. Mol. Microbiol. 45: 983-995.

Zavialov A.V., J. Berglund, A.F. Pudney, L.J. Fooks, T.M. Ibrahim, S. MacIntyre and S.D. Knight. 2003. Structure and biogenesis of the capsular F1 antigen from Yersinia pestis: preserved folding energy drives fiber formation. Cell 113: 587-596.

Zavialov A.V., V.M. Tischenko, L.J. Fooks, B.O. Brandsdal, J. Aqvist, V.P. Zav'yalov, S. Macintyre and S.D. Knight. 2005. Resolving the energy paradox of chaperone/usher-mediated fibre assembly. Biochem. J. 389: 685-694.

Zavialov A., G. Zav'yalova, T. Korpela and V. Zav'yalov. 2007. FGL chaperone-assembled fimbrial polyadhesins: anti-immune armament of Gram-negative bacterial pathogens. FEMS Microbiol. Rev. 31: 478-514.

Zav'yalov V.P., G.A. Zav'yalova, A.I. Denesyuk, M. Gaestel and T. Korpela. 1995. Structural and functional homology between periplasmic bacterial molecular chaperones and small heat shock proteins. FEMS Immunol. Med. Microbiol. 11: 265-272. 